Int. J. Dev. Biol. 49: 369-374 (2005)

doi: $10.1387 / \mathrm{ijdb} .041950 \mathrm{kk}$

\title{
Notch in vertebrates - molecular aspects of the signal
}

\author{
KEN-ICHI KATSUBE* and KEI SAKAMOTO \\ Molecular Pathology, Graduate School of Tokyo Medical and Dental University, Bunkyo-ku, Tokyo, Japan
}

\begin{abstract}
Notch is a receptor consisting of a single path transmembrane protein which is essential for stem cell regulation in both vertebrates and invertebrates. We have investigated the function of Notch signaling and found that ligands of the Notch receptor (Delta and Serrate) sometimes act as receptor modulators in a cell autonomous manner; the balance of their activity as ligands explains satisfactorily 'lateral inhibition' as well as 'lateral specification'. This model explains not only fly morphogenesis, but also the general regulation of stem cells. In vertebrates, members of a novel family of genes which encode small secretory proteins, CCN, were demonstrated to bind to Notch and stimulate signaling. This is not a ligand type binding, but rather a modifier of the protein structure of Notch, so as to form a macromolecular complex. This association may open up novel perspectives on Notch signaling, for instance in the movement of cells involved in somite segmentation or angiogenesis. Thus, a well-conserved signal such as Notch seems to have changed in function during the evolution of vertebrates.
\end{abstract}

KEY WORDS: Notch, CCN, oligomerization, body segmentation

I was in the «Institut d'Embryologie Cellulaire et Moléculaire» at Nogent-sur-Marne from October 1991 to March 1995. I had finished my PhD course of molecular biology just before coming to the institute and it was a completely new start for me to study embryogenesis. Without the basic knowledge of developmental biology, it was not easy to dig in the mine of institute and my life as post-doc in France was principally spent on the absorption of ideas fostered there. Professor Le Douarin is the dynamic center of ideas and the people in and out the institute assembled together to form some invisible web of intelligence. With the experience and observations, I have gradually raised my own idea and could extend a new field of research, Notch signaling, when I came back to Japan.

Molecular biology of eukaryote stands on the ideas principally established by the system of cell culture and simple concept is generally preferred. But in vivo study of embryo apparently indicates the complexity of morphological pattern formation and has not attracted molecular biologists for long time. The genetics of Drosophila and the studies of gene targeting of mice have opened up a new way of thinking for embryogenesis and the recent progress of developmental biology is remarkable. But still we are not so sure how the temporal and spatial patterning is orchestrated at molecular basis. Now the «Human genome project» was accomplished and all basic elements of genome are in our hands. However, life is not a simple puzzle or computer game, because the species is not fixed at a certain state, but rather, it gradually evolves to new one. The rules and combinations alter continually during evolution. We should not consider that the genes are stable elements.

Initially, Notch was discovered as a neurogenic gene during the study of Drosophila development (Dietrich and Campos-Ortega, 1984). At early 90's, it was demonstrated that Notch signal is well conserved in higher organisms including vertebrate and that it controls the proliferation and differentiation of stem cells (Weinmaster et al., 1991) (Chitnis et al., 1995) (de la Pompa et al., 1997). And more, in vertebrate, Notch signal has some different functions such as body segmentation (Conlon et al., 1995) (Hrabe de Angelis et al., 1997). Since the establishment of molecular cloning, a lot of genes have been identified and most of them are presumed to have more or less the same functions in both vertebrates and invertebrates. But Notch signal is a case that is differently used in development between vertebrate and invertebrate. Now it is necessary to elucidate the vertebrate specific evolution of gene employment.

\section{Notch ligands not only signal to receptors, but also} modulate receptor signalling

In Drosophila, a well-known model is demonstrated as «lateral inhibition» to explain the differentiation of neuroblasts (Figure 1A) (Cabrera, 1990) (Muskavitch, 1994). Neighboring cells in a proneural

Abbreviations used in this paper: EGF, epidermal growth factor; IGF, insulinlike growth factor.

\footnotetext{
*Address correspondence to: Dr. Ken-ichi Katsube. Molecular Pathology, Graduate School of Tokyo Medical and Dental University, Yushima 1-5-45, Bunkyoku, Tokyo, 113-8549 Japan. Fax +81-3-5803-0188. e-mail: katsube.mpa@tmd.ac.jp
} 
A lateral inhibition

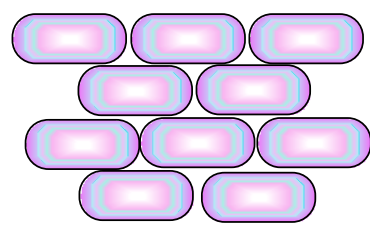

proneural cluster

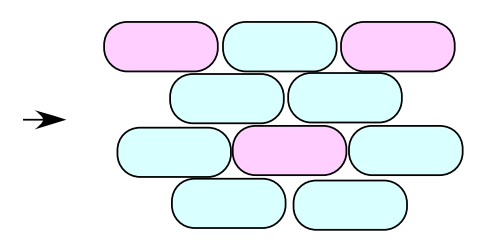

epidermoblast/neuroblast differentiation
B

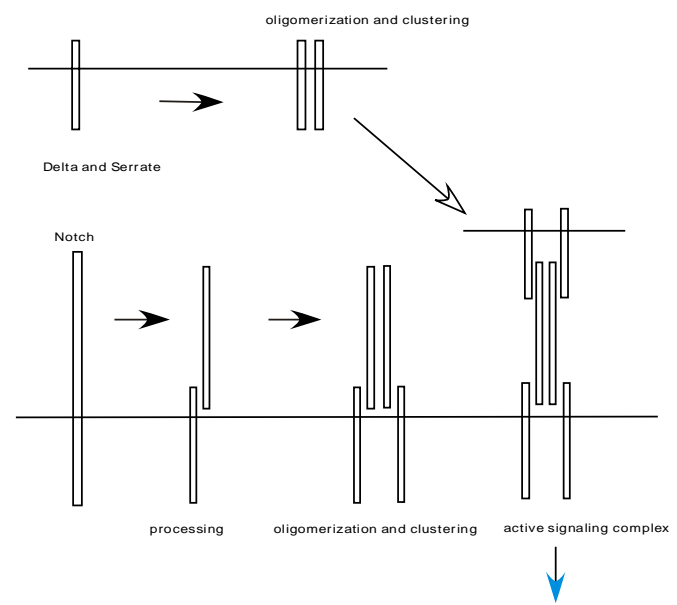

Fig. 1. Lateral inhibition and the Notch molecular complex. (A) Lateral inhibition in the development of fly neuroblasts. (B) Protein structure of Notch and its ligands. Homomeric oligomerization occurs before the formation of an active signaling complex.

cluster show no apparent difference at the beginning, but by some trigger, a cue is powered on to form the reciprocal patterning of two different types of progenitor cells, neuroblasts and epidermoblasts. In this process, cells differentiating to neuroblasts express Delta and inhibit the differentiation of neighboring cells to neuroblasts. Before the start of lateral inhibition, all cells in a proneural cluster have ubiquitous but weak expression of both Delta and Notch and desequilibration occurs spontaneously during the process of lateral inhibition. This transformation was confirmed by the genetic ablation in Drosophila, but the molecular basis of this spontaneous segregation and enhancement was not clarified. Now this hypothesis is extended to the concept of «lateral specification» that controls the two different types of cell from one resource (Chitnis, 1995).

Notch and its ligand, Delta are both single path transmembrane proteins and are believed to regulate the intercellular actions of lateral inhibition. But Notch ligands such as Delta and Serrate do not seem to possess active domain(s) in the intracellular region and it is difficult to explain how the interactive regulation occurs. Some complicated hypothesis was demonstrated by the analyses of genetic interaction in Drosophila. Positive and negative feedback like Domino between Notch and Delta is an often-used model to explain it (Heitzler and Simpson, 1993). But this model is not supported by any molecular evidence and we would like to suggest a simple concept to explain the lateral inhibition/specification.

This idea was raised from the observations of in ovo transfection (Sakamoto et al., 1998) of Delta dominant negative to the neural stem cells (Sakamoto et al., 2002a). «Dominant negative» is usually employed for a defective molecule that counterparts the intact one so as to inhibit the formation of normal complex, which is biologically inactive. But in the case of Delta dominant negative, it exerts its effect as an inhibitor on its receptor, the Notch protein rather than on Delta itself. We investigated several differentiation markers and concluded that the effect of Delta dominant negative occurred in a cell autonomous manner, which is very strange because ligand generally acts in a cell non-autonomous (intercellular) manner.

Genetic interaction in Drosophila indicated the homomeric oligomerization must occur in both Notch and its ligands, Delta and Serrate. We have confirmed it by biochemical assays (Figure 1B). This type of oligomerization was reported in immunoreceptor complex such as TNF- $\alpha$ family genes and their receptors. We investigated the cell autonomous action of Delta dominant negative by the aspect of oligomerization. Extended experiments with some other deleted forms of ligands indicated that Notch ligands (both Delta and Serrate) associate with their receptor, Notch, in the same cell. In other words, the ligand sometimes acts as a receptor modulator (Figure 2). Strikingly, this heteromeric combination controls the cellular locality of Notch protein (Figure 2). Homomeric complex of Notch protein exhibits on the cell surface meanwhile heteromeric complex retains in some intracellular region, probably the endoplasmic reticulum (ER) or Golgi apparatus. In summary, expression of Notch ligand stimulates Notch signaling in neighboring cells, but suppresses Notch receptivity in a cell autonomous manner. We concluded that the «dominant negative» effect of truncated Delta comes from the enhanced effect of cell autonomous function and the loss of function as ligand. This model explains well the catastrophic progression of lateral inhibition/specification (Figure 3). Once dose imbalance occurs between Notch and Delta, Notch
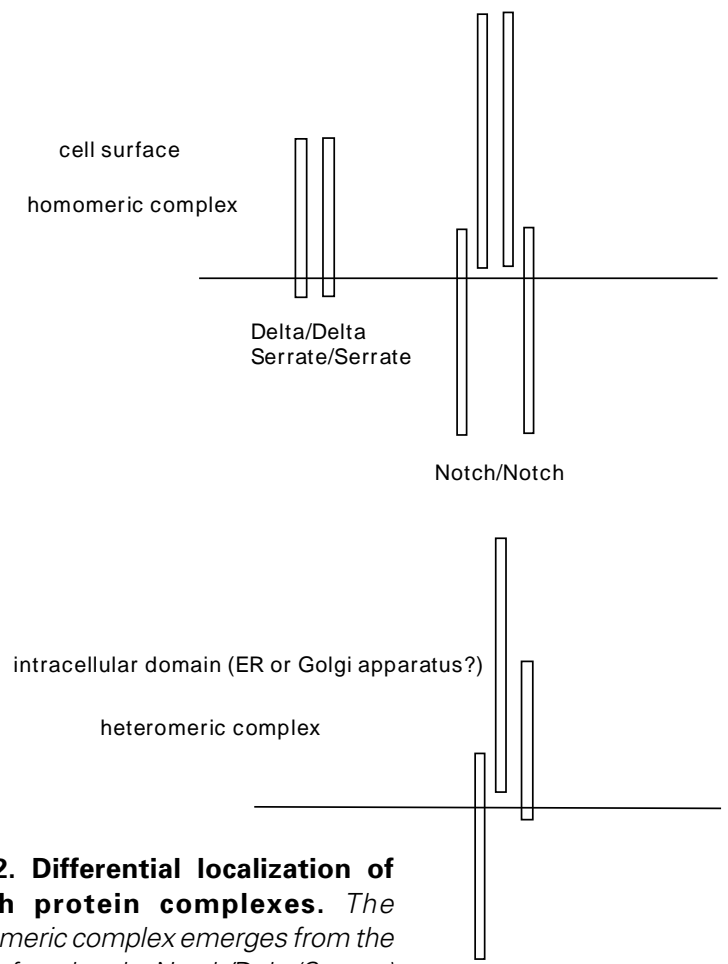

homomeric complex emerges from the cell surface, but the Notch/Delta(Serrate) heteromeric complex remains in the intracellular domain.
Notch/Delta Notch/Serrate 
expressing cells express Notch more strongly and Delta expressing cells express Delta more strongly. This progression is supported by both cell nonautonomous (intercellular) activation of Notch signaling and cell autonomous repression of Notch presentation by Delta. Notch ligands are transmembrane proteins and these membrane-anchored forms are necessary for the proper action as ligand and receptor modulator. This fact indicates that some unknown adaptor-like protein associates with the intracellular domain of Notch ligands. Several different types of transmembrane or membrane associated ligands exist such as TNF- $\alpha$ and scf (a ligand of c-kit) and their truncated soluble forms loose biological activity as ligands (Decoster et al., 1995, Wehrle-Haller and Weston, 1995). These ligands regulate stem cells and it might be possible to assume that membrane anchored ligand/receptor signaling is important for their maintenance.

Fringe, a glycosyltransferease of Notch protein, modulates Notch signaling in cell autonomous and cell non-autonomous manner (Moloney et al., 2000). We investigated its effect in Notch complex formation and found that Fringe glycosylation inhibits the formation of heteromeric complex between Notch and its ligand. This effect probably forces to present the homomeric complex of Notch to the cell surface and enhances its receptivity (Figure 4). These results tell us the reason why the fringe glycosylation enhances the Notch signaling cell-autonomously.

Notch and its ligand have a unique character in association and lateral inhibition/specification seems to be controlled on this basis. One thing that is not fully understood is the initial step. Like the chain reaction of atomic division, the destabilization of balance would occur by some trigger, but this would be due to some other factor(s) than Notch signaling.

\section{Novel CCN molecules which regulate Notch signaling were created during vertebrate evolution}

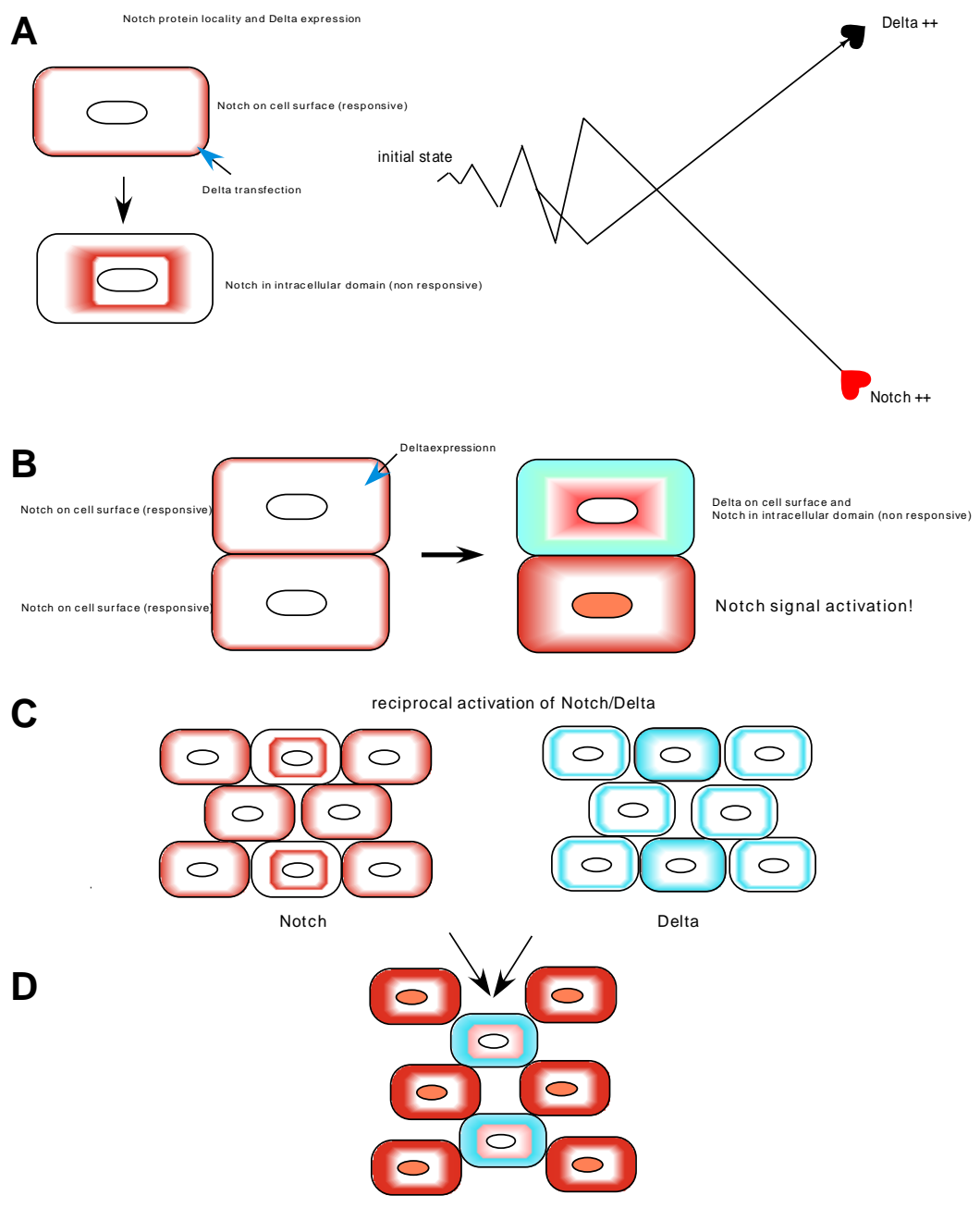

Fig. 3. Molecular mechanism of lateral inhibition/specification. (A) Enhanced expression of Delta suppresses the presentation of Notch to the cell surface. (B) Notch receptor of a neighboring cell to the Delta + cell is stimulated. Reciprocal enhancement of Notch and Delta is activated. (C) Reciprocal pattern of Notch and Delta expression is enhanced in proneural cluster. (D) Each cell chooses the bimodal fate of differentiation of Notch and Delta during lateral inhibition.
Notch receptor is originally produced as a single path transmembrane protein, but it receives at least three processings. The cleavages are created by different proteases; Furin (Roebroek etal., 1993), Kuzbanian (TACE) (Yavari etal., 1998) and Presenilin (Boulianne et al., 1997). These modifications and Fringe glycosylation are well conserved in the evolution of vertebrates and invertebrates.

CCN is a newly identified family of genes (Perbal, 2001) (Brigstock etal., 2003)and is believed to evolve only in vertebrates, which was indicated by the analyses of human and mouse genome project (personal communication). CCN is a type of small secretory protein that has four principal domains, IGFBP (homologous to $\mathrm{N}$ terminal region of insulin-like growth factor (IGF) binding protein, but not a binding domain to IGF), VWC (von Willebrand factor type C), TSP1 (thrombospondin type I) and CT (C-terminal region rich in cysteines) (Figure 5A). Main members of CCN are Cyr61 (Cysteine rich protein, CCN1 ) (O'Brien et al., 1990), CTGF (Connective tissue growth factor, CCN2) (Bradham etal., 1991)and
Nov (Nephroblastoma overexpressed gene, CCN3) (Perbal, 1994), which were identified in several different research projects. The twisted gastrulation (tsg) invertebrate gene (Mason et al., 1994) has an equivalent gene family in vertebrates (mammalian tsg) (Graf etal., 2001). Recently we investigated the expression of CCN3 during early embryogenesis(Katsube et al., 2001). It expressed strongly in paraxial and axial structures such as presomitic mesoderm, which resembles Notch1 expression pattern and co-immunoprecipitation assay demonstrated that Notch1 could associate with CCN3 in the extracellular domain(Sakamoto et al., 2002b). In CCN3, the CT region is responsible for binding ability, but Notch1 has several different sites in epidermal growth factor (EGF)motif repeats that are recognized by CCN3 (Figure 5B). These results indicate that CCN3 is not a ligand of Notch1 but a type of accessory molecule that modifies the Notch1 protein structure. It might be possible to change the oligomerization activity of Notch1 by its dimerization. Binding of CCN3 could activate the downstream of Notch signal such as HES1 or HES5 by itself. The 
Fig. 4. The glycosylation by Fringe dissociates the heteromeric complex of Notch/Delta (also Notch/Serrate) and homomeric complex of Notch occurs. This explains the cell-autonomous enhancement of Notch signaling by Fringe.

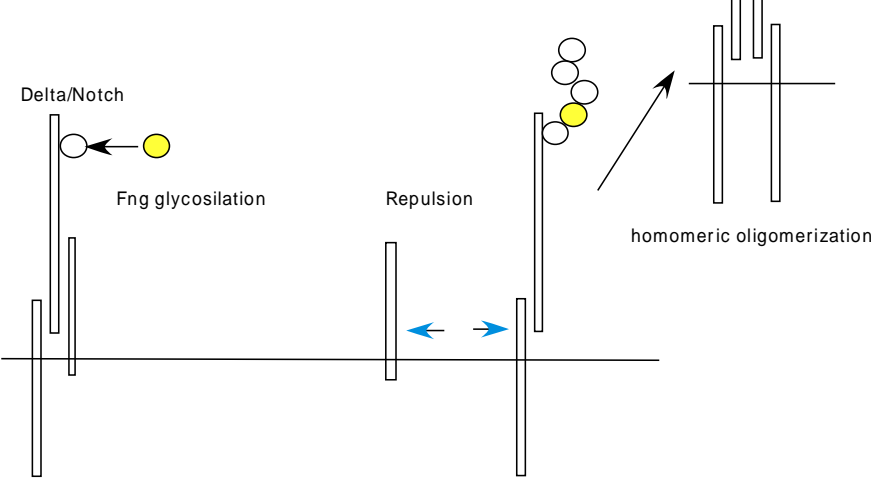

signal activation could promote the antagonistic effect on cell differentiation of a myogenic cell line, C2/4 (a subline of C2C12). This is the first demonstration that a protein other than authentic Notch ligands can regulate the Notch signal. This may indicate another aspect of Notch protein, namely, that its signal activation depends on its oligomerization, which differs much from other types of signaling of membranous receptor. At present, the counterparts of CCN molecules belong to several different types of proteins such as Fibuin1 (Perbal et al., 1999), integrin(Chen et al., 2000), BMP(Abreu et al., 2002), VEGF(Inoki et al., 2002) and also other members of $\mathrm{CCN}$ to form the mutual heteromeric dimers(Perbal et al., 1999). Some other unknown molecules will bind to the CCN molecule and influence its activity.

Notch receptor in vertebrate is surrounded by other types of extracellular and transmembrane proteins via CCN bridges. Of course, this is the aspect viewed from the Notch protein. It seems correct to say that the macrocomplex of extracellular proteins is formed by a glue-like protein, CCNs and that Notch is involved in it. The members of this complex would be changed depending on the types of cells and CCN seems to contribute as a scaffold protein to constitute a dynamic extracellular protein complex.

\section{Somite segmentation and Notch signal}

Recent reports often mention that the master plan of body patterning seems common to vertebrates and invertebrates. Anterio-posterior gradient of Hox gene family is a well-known example (Fienberg et al., 1987) and it has become a fashion to discuss developmental mechanisms in a similar manner. But as we see in case of Wnt (Gavin et al., 1990) or Hedgehog (Fietz et al., 1994), the vertebrate equivalents of these segment polarity genes are not involved in anterio-posterior patterning of body segment but in dorso-ventral polarity of body axis.

As for Notch signaling, it is certainly involved in the regulation of stem cells in both organisms (Chan and Jan, 1999), but in vertebrates, Notch signal is also used for body patterning, such as somite segmentation (Conlon et al., 1995; Hrabe de Angelis et al., 1997; Johnston et al., 1997). Somitogenesis can be classified according to two independent aspects; the growth and differentiation of somitic stem cells and the segmentation of somite structure (Palmeirim et al., 1998). Notch signal regulates the stem cells in somite and also plays a critical role in the segmentation. Body segmentation is also observed in invertebrates, but invertebrates apply completely different sets of genes, named as Gap and pair rule (Nusslein-Volhard and Wieschaus, 1980). Phenotypically, vertebrates and invertebrates possess the same pattern formation, but their difference in molecular mechanism is discrete. Essentially, molecular functions and interactions of gene product have not been altered during evolution, so what is the cause of change of use?

One possible hypothesis is the creation of new genes, which add a novel modification or path to the existing set of genes. As mentioned in the previous paragraph, Notch protein is surrounded by other molecules in vertebrates. Integrin is a large family of transmembrane receptors constituted with heteromeric complex of $\alpha$ and $\beta$ subunits. It has different ligands such as laminin, collagen and fibronectin and controls the cell motility or migration. Several integrins were reported to be involved in somite segmentation and especially the $\beta 1$ subunit seems important (Drake et al., 1992;

A

CCN family of Genes
\begin{tabular}{|c|c|c|c|}
\hline IGFBP & VWC & TSP1 & CT \\
\hline
\end{tabular}

B

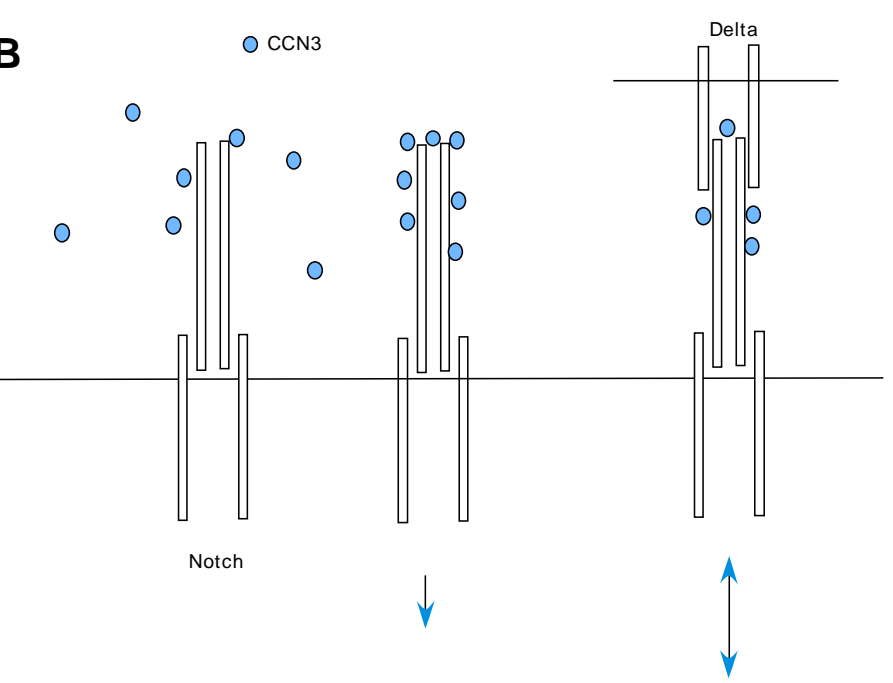

Fig. 5. The association of CCN protein modulates the Notch signal. (A) Basic structure of the CCN family of genes. IGFBP (homologous to Nterminal region of insulin-like growth factor [IGF] binding protein, but not a binding domain to (GF), VWC (von Willebrand factor type C), TSP1 (thrombospondin type I) and CT (C-terminal region rich in cysteines). (B) CCN3 can associate Notch 1 in EGF motifs and stimulates Notch signaling. Effect of trimeric complex of Notch/Delta/CCN3 is not yet determined. 


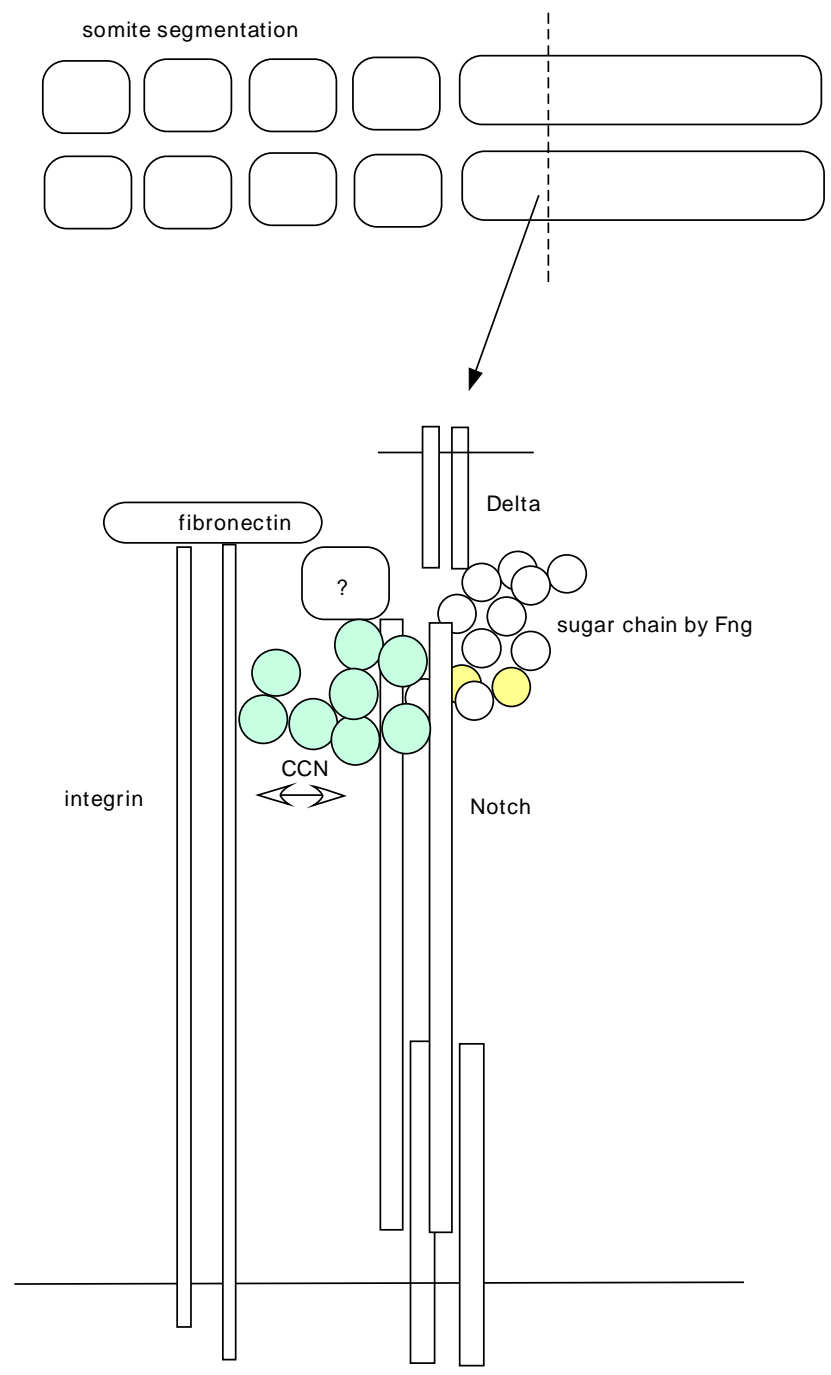

Fig. 6. Hypothetical network of proteins in the area of somite segmentation. Integrin may be related with Notch1 via bridge of CCN and this interaction may cause remodeling of somitic structure.

Drake and Little, 1991). Direct evidence is not yet demonstrated because null mutants of $\beta 1$ integrin died in the implantation stage (Stephens et al., 1995). This integrin was recently reported to associate with CCN1, which influences the remodeling pattern of endothelial cells during angiogenesis (Chen et al., 2000). $\alpha 6 \beta 1$ integrin was reported to be expressed in somitogenesis (Pow and Hendrickx, 1995). The adhesion ability of the integrin family changes rapidly with «inside-out» and «outside-in» effects by cytokines (Ginsberg et al., 1992; Takagi et al., 2002) and it may be possible to think that integrin regulates the movement of somitic cells so as to form the somite segment cooperating with Notch signaling (Figure 6) via CCN. In the remodeling step of angiogenesis, direct interaction of Notch4 and $\beta$ 1integrin is important (Leong et al., 2002). $\beta 1$ integrin was also reported to interact with CCN1 and to regulate the angiogenesis (Grzeszkiewicz et al., 2002). CCN is a candidate molecule that induces the cell migration activity of Notch signal in somite segmentation, but at present single knockouts of CCN1 (Mo etal., 2002) and CCN2 (Ivkovic etal., 2003) demonstrated the perturbation of angiogenesis but not of somite segmentation.
Genetic redundancy may exist in the area of somitogenesis since overlapping expression among CCNs was observed there. Clockwise change of gene expression of some Notch signal genes such as lunatic Fringe (McGrew et al., 1998), hairy1 (Palmeirim et al., 1997) and hairy2 (Davis et al., 2001) is essential for the timing (oscillation) of somite segmentation, but the $\mathrm{CCN}$ relationship with these clock genes remains to be elucidated. Further investigation is necessary to elucidate the role of $\mathrm{CCN}$ in somitogenesis.

In vertebrates, the role of Notch signaling is not limited to the developmental stage. Notch1 contributes to tumorigenesis such as leukemia (human and mice) or uterine cervical cancer. Regulator cell cycle genes(p21, E6/E7) were reported to be involved in this process (Sriuranpong et al., 2001; Talora et al., 2002), but these types of association were not confirmed in invertebrates. With the evolution of vertebrates, some components of the genetic web of Notch signaling seemed to be transformed for the convenience of life. At the time of discovery, it was very surprising that invertebrates and vertebrates conserve homologous genes, but now the time has come to think about the difference in their usage.

We started the study of Notch signaling by in ovo experiments and at present, we are interested in its molecular interactions. $L e$ coeur est à gauche. Le capital est à droite. (The heart is to the left. Money is to the right.) is believed to indicate the mentality of the French people regarding politics. If I apply this expression to explain my situation, I can say "Motif is in the molecule. Motive is still in morphology.»

\section{References}

ABREU, J.G., KETPURA, N.I., REVERSADE, B. and DE ROBERTIS, E.M. (2002). Connective-tissue growth factor (ctgf) modulates cell signalling by bmp and tgfbeta. Nat Cell Biol 4: 599-604.

BOULIANNE, G.L., LIVNE-BAR, I., HUMPHREYS, J.M., LIANG, Y., LIN, C., ROGAEV, E. and ST GEORGE-HYSLOP, P. (1997). Cloning and characterization of the Drosophila presenilin homologue. Neuroreport 8: 1025-9.

BRADHAM, D.M., IGARASHI, A., POTTER, R.L. and GROTENDORST, G.R. (1991). Connective tissue growth factor: A cysteine-rich mitogen secreted by human vascular endothelial cells is related to the src-induced immediate early gene product cef-10. J Cell Biol 114: 1285-94.

BRIGSTOCK, D.R., GOLDSCHMEDING, R., KATSUBE, K.I., LAM, S.C., LAU, L.F., LYONS, K., NAUS, C., PERBAL, B., RISER, B., TAKIGAWA, M. et al. (2003). Proposal for a unified ccn nomenclature. Mol Pathol 56: 127-8.

CABRERA, C.V. (1990). Lateral inhibition and cell fate during neurogenesis in drosophila: The interactions between scute, notch and delta. Development 110: 733-42.

CHAN, Y.M. and JAN, Y.N. (1999). Conservation of neurogenic genes and mechanisms. Curr Opin Neurobiol 9: 582-8.

CHEN, N., CHEN, C.C. and LAU, L.F. (2000). Adhesion of human skin fibroblasts to cyr61 is mediated through integrin alpha 6 beta 1 and cell surface heparan sulfate proteoglycans. J Biol Chem 275: 24953-61.

CHITNIS, A., HENRIQUE, D., LEWIS, J., ISH-HOROWICZ, D. and KINTNER, C. (1995). Primary neurogenesis in xenopus embryos regulated by a homologue of the Drosophila neurogenic gene delta. Nature 375: 761-6.

CHITNIS, A.B. (1995). The role of notch in lateral inhibition and cell fate specification. Mol Cell Neurosci 6: 311-21.

CONLON, R.A., REAUME, A.G. and ROSSANT, J. (1995). Notch1 is required for the coordinate segmentation of somites. Development 121: 1533-45.

DAVIS, R.L., TURNER, D.L., EVANS, L.M. and KIRSCHNER, M.W. (2001). Molecular targets of vertebrate segmentation: Two mechanisms control segmental expression of xenopus hairy2 during somite formation. Dev Cell 1: 553-65.

DE LA POMPA, J.L., WAKEHAM, A., CORREIA, K.M., SAMPER, E., BROWN, S., AGUILERA, R.J., NAKANO, T., HONJO, T., MAK, T.W., ROSSANT, J. et al. (1997). Conservation of the notch signalling pathway in mammalian neurogenesis. Development 124: 1139-48. 
DECOSTER, E., VANHAESEBROECK, B., VANDENABEELE, P., GROOTEN, J. and FIERS, W. (1995). Generation and biological characterization of membranebound, uncleavable murine tumor necrosis factor. J Biol Chem 270: 18473-8.

DIETRICH, U. and CAMPOS-ORTEGA, J.A. (1984). The expression of neurogenic loci in imaginal epidermal cells of Drosophila melanogaster. JNeurogenet 1 : 315-32.

DRAKE, C.J., DAVIS, L.A., HUNGERFORD, J.E. and LITTLE, C.D. (1992). Perturbation of beta 1 integrin-mediated adhesions results in altered somite cell shape and behavior. Dev Biol 149: 327-38.

DRAKE, C.J. and LITTLE, C.D. (1991). Integrins play an essential role in somite adhesion to the embryonic axis. Dev Biol 143: 418-21.

FIENBERG, A.A., UTSET, M.F., BOGARAD, L.D., HART, C.P., AWGULEWITSCH, A., FERGUSON-SMITH, A., FAINSOD, A., RABIN, M. and RUDDLE, F.H. (1987). Homeo box genes in murine development. Curr Top Dev Biol 23: 23356.

FIETZ, M.J., CONCORDET, J.P., BARBOSA, R., JOHNSON, R., KRAUSS, S., MCMAHON, A.P., TABIN, C. and INGHAM, P.W. (1994). The hedgehog gene family in Drosophila and vertebrate development. Dev Supp/43-51.

GAVIN, B.J., MCMAHON, J.A. and MCMAHON, A.P. (1990). Expression of multiple novel wnt-1/int-1-related genes during fetal and adult mouse development. Genes Dev 4: 2319-32.

GINSBERG, M.H., DU, X. and PLOW, E.F. (1992). Inside-out integrin signalling. Curr Opin Cell Biol 4: 766-71.

GRAF, D., TIMMONS, P.M., HITCHINS, M., EPISKOPOU, V., MOORE, G., ITO, T. FUJIYAMA, A., FISHER, A.G. and MERKENSCHLAGER, M. (2001). Evolutionary conservation, developmental expression and genomic mapping of mammalian twisted gastrulation. Mamm Genome 12: 554-60.

GRZESZKIEWICZ, T.M., LINDNER, V., CHEN, N., LAM, S.C. and LAU, L.F. (2002). The angiogenic factor cysteine-rich 61 (cyr61, ccn1) supports vascular smooth muscle cell adhesion and stimulates chemotaxis through integrin alpha(6)beta(1) and cell surface heparan sulfate proteoglycans. Endocrinology 143: 1441-50.

HEITZLER, P. and SIMPSON, P. (1993). Altered epidermal growth factor-like sequences provide evidence for a role of notch as a receptor in cell fate decisions. Development 117: 1113-23.

HRABE DE ANGELIS, M., MCINTYRE, J., 2ND and GOSSLER, A. (1997). Maintenance of somite borders in mice requires the delta homologue dii1. Nature 386: 717-21.

INOKI, I., SHIOMI, T., HASHIMOTO, G., ENOMOTO, H., NAKAMURA, H., MAKINO, K., IKEDA, E., TAKATA, S., KOBAYASHI, K. and OKADA, Y. (2002). Connective tissue growth factor binds vascular endothelial growth factor (vegf) and inhibits vegf-induced angiogenesis. FASEB $J$ 16: 219-21.

IVKOVIC, S., YOON, B.S., POPOFF, S.N., SAFADI, F.F., LIBUDA, D.E., STEPHENSON, R.C., DALUISKI, A. and LYONS, K.M. (2003). Connective tissue growth factor coordinates chondrogenesis and angiogenesis during skeletal development. Development 130: 2779-91.

JOHNSTON, S.H., RAUSKOLB, C., WILSON, R., PRABHAKARAN, B., IRVINE, K.D. and VOGT, T.F. (1997). A family of mammalian fringe genes implicated in boundary determination and the notch pathway. Development 124: 2245-54.

KATSUBE, K., CHUAI, M., LIU, Y., KABASAWA, Y., TAKAGI, M., PERBAL, B. and SAKAMOTO, K. (2001). The expression of chicken nov, a member of the ccn gene family, in early stage development. Gene Expression Patterns 1: 61-65.

LEONG, K.G., HU, X., LI, L., NOSEDA, M., LARRIVEE, B., HULL, C., HOOD, L., WONG, F. and KARSAN, A. (2002). Activated notch4 inhibits angiogenesis: Role of beta 1-integrin activation. Mol Cell Biol 22: 2830-41.

MASON, E.D., KONRAD, K.D., WEBB, C.D. and MARSH, J.L. (1994). Dorsal midline fate in Drosophila embryos requires twisted gastrulation, a gene encoding a secreted protein related to human connective tissue growth factor. Genes Dev 8: 1489-501.

MCGREW, M.J., DALE, J.K., FRABOULET, S. and POURQUIE, O. (1998). The lunatic fringe gene is a target of the molecular clock linked to somite segmentation in avian embryos. Curr Biol 8: 979-82.

MO, F.E., MUNTEAN, A.G., CHEN, C.C., STOLZ, D.B., WATKINS, S.C. and LAU, L.F. (2002). Cyr61 (ccn1) is essential for placental development and vascular integrity. Mol Cell Biol 22: 8709-20.
MOLONEY, D.J., PANIN, V.M., JOHNSTON, S.H., CHEN, J., SHAO, L., WILSON, R. WANG, Y., STANLEY, P., IRVINE, K.D., HALTIWANGER, R.S. etal. (2000). Fringe is a glycosyltransferase that modifies notch. Nature 406: 369-75.

MUSKAVITCH, M.A. (1994). Delta-notch signaling and Drosophilacell fate choice. Dev Biol 166: 415-30.

NUSSLEIN-VOLHARD, C. and WIESCHAUS, E. (1980). Mutations affecting segment number and polarity in drosophila. Nature 287: 795-801.

O'BRIEN, T.P., YANG, G.P., SANDERS, L. and LAU, L.F. (1990). Expression of cyr61, a growth factor-inducible immediate-early gene. Mol Cell Biol 10: 3569-77.

PALMEIRIM, I., DUBRULLE, J., HENRIQUE, D., ISH-HOROWICZ, D. and POURQUIE, O. (1998). Uncoupling segmentation and somitogenesis in the chick presomitic mesoderm. Dev Genet 23: 77-85.

PALMEIRIM, I., HENRIQUE, D., ISH-HOROWICZ, D. and POURQUIE, O. (1997). Avian hairy gene expression identifies a molecular clock linked to vertebrate segmentation and somitogenesis. Cel/ 91: 639-48.

PERBAL, B. (1994). Contribution of mav-1-induced nephroblastoma to the study of genes involved in human Wilms' tumor development. Crit Rev Oncog 5: 589-613.

PERBAL, B. (2001). The ccn family of genes: A brief history. Mol Pathol 54: 103-4.

PERBAL, B., MARTINERIE, C., SAINSON, R., WERNER, M., HE, B. and ROIZMAN, $B$. (1999). The c-terminal domain of the regulatory protein novh is sufficient to promote interaction with fibulin 1c: A clue for a role of novh in cell-adhesion signaling. Proc Natl Acad Sci USA 96: 869-74.

POW, C.S. and HENDRICKX, A.G. (1995). Localization of integrin subunits alpha 6 and beta 1 during somitogenesis in the long-tailed macaque (m. Fascicularis). Cell Tissue Res 281: 101-8.

ROEBROEK, A.J., CREEMERS, J.W., PAULI, I.G., BOGAERT, T. and VAN DE VEN, W.J. (1993). Generation of structural and functional diversity in furin-like proteins in Drosophila melanogaster by alternative splicing of the dfur1 gene. EMBO J 12 : 1853-70

SAKAMOTO, K., NAKAMURA, H., TAKAGI, M., TAKEDA, S. and KATSUBE, K. (1998) Ectopic expression of lunatic fringe leads to downregulation of serrate- 1 in the developing chick neural tube; analysis using in ovo electroporation transfection technique. FEBS Lett 426: 337-41.

SAKAMOTO, K., OHARA, O., TAKAGI, M., TAKEDA, S. and KATSUBE, K. (2002a). Intracellular cell-autonomous association of notch and its ligands: A novel mechanism of notch signal modification. Dev Biol 241: 313-26.

SAKAMOTO, K., YAMAGUCHI, S. andO, R., MIYAWAKI, A., KABASAWA, Y., TAKAGI, M., LI, C.L., PERBAL, B. and KATSUBE, K. (2002b). The nephroblastoma overexpressed gene (nov/ccn3) protein associates with notch1 extracellular domain and inhibits myoblast differentiation via notch signaling pathway. J Bio/Chem 277: 29399-405.

SRIURANPONG, V., BORGES, M.W., RAVI, R.K., ARNOLD, D.R., NELKIN, B.D. BAYLIN, S.B. and BALL, D.W. (2001). Notch signaling induces cell cycle arrest in small cell lung cancer cells. Cancer Res 61: 3200-5.

STEPHENS, L.E., SUTHERLAND, A.E., KLIMANSKAYA, I.V. and RIEUX, A., MENESES, J., PEDERSEN, R.A. and DAMSKY, C.H. (1995). Deletion of beta 1 integrins in mice results in inner cell mass failure and peri-implantation lethality. Genes Dev 9: 1883-95.

TAKAGI, J., PETRE, B.M., WALZ, T. and SPRINGER, T.A. (2002). Global conformational rearrangements in integrin extracellular domains in outside-in and inside-out signaling. Cel/ 110: 599-11.

TALORA, C., SGROI, D.C., CRUM, C.P. and DOTTO, G.P. (2002). Specific downmodulation of notch1 signaling in cervical cancer cells is required for sustained hpve6/e7 expression and late steps of malignant transformation. Genes Dev 16: 2252 63.

WEHRLE-HALLER, B. and WESTON, J.A. (1995). Soluble and cell-bound forms of steel factor activity play distinct roles in melanocyte precursor dispersal and survival on the lateral neural crest migration pathway. Development 121: 731-42.

WEINMASTER, G., ROBERTS, V.J. and LEMKE, G. (1991). A homolog of Drosophila notch expressed during mammalian development. Development 113: 199-205.

YAVARI, R., ADIDA, C., BRAY-WARD, P., BRINES, M. and XU, T. (1998). Human metalloprotease-disintegrin kuzbanian regulates sympathoadrenal cell fate in development and neoplasia. Hum Mol Genet 7: 1161-7. 